\title{
MARKING UKRAINE'S PUbLIC SPACE AS INTERACTION OF LANGUAGE AND IDEOLOGY: PAST AND PRESENT
}

\author{
Halyna Matsyuk \\ Ivan Franko National University in Lviv, Ukraine
}

\begin{abstract}
In this paper, the interaction between linguistic sign and its ideological content has been researched by applying a linguistic sociopolitical approach. Proceeding from the symbolic function of linguistic landscape, the study explains the legal mechanisms of introducing Soviet ideology into Ukraine's urban public space, the reasons for changing linguistic landscape after gaining independence in 1991, and the choice of new names to replace signs with Soviet semantics. The findings suggest that some entities of urban semantic space before and after 1991 have been linked to divergent state and state-building ideologies.
\end{abstract}

Keywords: linguistic landscape, sign symbolic function, ideology, renaming.

\section{Introduction}

The linguistic landscape of Ukraine has already become the object of interdisciplinary studies: political analysts, geographers, sociologists, historians, sociolinguists, and experts in onomastics have evinced increasing interest in public-space naming. Researchers (Halay 2009; Tytarenko 2015; Khrushkova 2016; Yatskiv 2013 etc.) devote particular attention to urban names. Linguistic landscape (hereinafter LL) manifests itself as a dynamic phenomenon in diachronic context taking into account language changes and language conflict, language policy and multilingual practice (Pavlenko 2009; Pavlenko 2010; Bever 2010). Nonetheless, few scholars have explicitly theorized certain major issues, including the analysis of the political and legislative background of renaming processes, the strategic significance of replacing Soviet LL as a national security issue, and modern state policy of national memory. Similarly, understanding the nature of visualising new values through modern LL signs has not been adequately addressed.

Following a ground-breaking study by Landry and Bourhis (1997), researchers have sought to enhance the efficiency of exploring the social construction of public space by providing insight into the symbolic function of LL signs. These studies have become the major impetus behind the present paper, which addresses the interaction of linguistic sign and its ideological content in the linguistic space of Ukrainian urban areas in the Soviet era and after the declaration of Ukraine's independence in 1991. By initiating an in-depth discussion of this aspect of research, there is the intention to contribute to the development of the theory of political and social onomastics and 
the theory of sociolinguistics, as well as to broaden the scope of issues related to LL discussed within geosemiotics, which is a cutting-edge research field.

\section{Research methodology}

Broadly speaking, I have adopted a linguistic sociopolitical approach to study the interaction between linguistic sign and its ideological content. It largely relies upon the conceptual premises of the theory of LL with regard to the functions of names in the semantic space of urban areas (Ben-Rafael et al. 2006; Ben-Rafael et al. 2010; Jaworski and Yeung 2010); the theory of language and identity interaction in sociocultural context (Bucholtz and Hall 2005; Nahorna 2008; Kozlovets 2009; Matsyuk 2014); the theory of political ideology in relation to Ukraine's transition from totalitarianism to the development of fundamental democratic principles of coexistence and market relations (Kyrylyuk 2009). It also makes particular use of the ideas of onomastics pertaining to the specific aspects of creating toponyms, urban names, and other means for marking public space (Luchyk 2009). Discourse, comparative, and event analysis were applied to the signs used to rename the public space of Ukrainian cities during the period of the USSR and the years of independence (1991-2017).

The corpus contains a comprehensive list comprising the names of cities, towns, villages, streets, lanes, squares, districts, etc. collected from paper and electronic media. It seems vital to analyse those relatively unknown aspects of renaming processes in the public space of two types of Ukraine, namely the Soviet one and the independent one, which could help to expose and elucidate the interaction of language and ideology. Therefore, it is pertinent to consider the following: 1) the symbolic function of LL as a means of constructing Soviet ideology and the legal mechanisms for its implementation in public semantic space; 2) the reasons for changing LL and the choice of new names for replacing the signs with Soviet semantics; 3 ) the correlative interaction of linguistic sign and its ideological content in LL before and after 1991.

\section{Symbolic function of LL, construction of Soviet ideology, and legal mechanisms of its introduction into the public space of Soviet Ukraine}

As previously stated, LL signs perform an informational and a symbolic function (Landry and Bourhis 1997). Through their form and content, they make society's ideological values visible. Therefore, LL signs assume the role of a powerful instrument in state hands. A state has a strong possibility to take advantage of the symbolic landscape to consolidate its ideology.

Before embarking on the examination of LL signs in Ukraine, it is essential to delineate the notion of ideology to avoid possible conflicting interpretations. Dictionaries of political studies define ideology as a system of political, legal, ethical, artistic, cultural, religious, and philosophical views that are part of public consciousness. Their role is to preserve allegiance to a certain set of ideals or to suggest social changes. Thus, ideology always expresses certain social values (Entsyklopedychnyi slovnyk 2010: 267-266; Karasevych and Shachkovska 2016: 137-138). 
The comprehensive empirical data that I collected and analysed in the process of research suggests that pre-Soviet LL signs, as a rule, reflected a distinctive character of a particular area, identified the location of certain objects of nomination, and occasionally manifested the ideological content associated with royal persons or an event of national significance. Conversely, since its early years, the Soviet government intensified the ideological narrative in public space naming. For example, in 1919 in Kharkiv, the first Soviet names with ideological content appeared in public space: Karl Liebknecht Street, in honour of German and international labour movement activist, one of the founders of the Communist Party of Germany (instead of Sumy Street); Rosa Luxemburg Square, in honour of German labour movement leader, one of the founding members of the Communist Party of Germany (instead of Mykolayiv Street). In the following years, a similar practice of introducing new LL signs was adopted in every Ukrainian city. An ideologically-driven naming process intended to visualise the values of a new Soviet system. The latter stigmatised and eliminated the so-called "class-alien" public space names which were related to the gentry and noble class as well as religion: Velykyi i Malyi Filvarok ('Great and Little Folwark') (Lviv Region) was changed to Velykyi i Malyi Pryhorodok ('Great and Little Suburb'); Sultanovka ('related to Sultan') (South Ukraine) - Yuzhne ('South'); Yanholy ('Angels') (Kherson Region) - Peredove ('related to Soviet leading workers'). Communist symbols were represented by typical names with a high frequency throughout Soviet Ukraine: Pershotravneve ('The First of May'), Leninske ('Lenin'), Soviet, Ulyanovka ('Ulyanov' - Lenin's real surname), etc. After World War II, there was a massive change in the historical names associated with the Germans, Crimean Tatars, and Poles. Nationally marked names throughout the country were gradually substituted by neutral ones, for instance, Ivanivka, Mykhailivka, and Yosypivka (derivatives of the names Ivan, Mykhailo, and Yosyp).

It is noteworthy that LL was promptly losing its informative function to become standardised throughout the state. All residential areas were forced to include certain thematic groups to their public space: the names associated with the October Revolution and the advent of the Bolsheviks' rule (Lenin, Artem, Budyonnyi, Voroshylov); the phenomena of the Soviet political system (Pioneers, the Komsomol, the Communist Party); the newly introduced public holidays (Soviet Army Day, May Day); the Russian ideologues of the revolutionary movement canonised by the Soviet propaganda (Herzen, Dobrolyubov, Chernyshevskyi); the foreign revolutionaries and leaders of world communism (Babel, Dimitrov, Liebknecht, Luxemburg, Engels, Marx). One of the Soviet linguistic universals was the thematic group "The Creators of the Communist Ideology": Lenin, Marx, Engels et al. The central part of every locality was marked by this set of entities. It is highly relevant to the discussion that these names were alien to local cultures and were brought into their symbolic space in order to form a new Soviet identity of the Ukrainian Soviet Socialist Republic.

What is particularly striking is that Soviet LL signs had their specific sender: state power was the only actor of political communication. Thus, LL signs were 
decontextualised top-down entities, which were not related to any place and had the same form and content in different localities of Soviet Ukraine.

Notwithstanding the fact that the Soviet government began the renaming from the first years of its rule, the legislative framework was introduced much later. One of the first documents (Ukaz Prezydyuma... 1957: 579-581) defined the procedure for giving names of state and public figures to regions, towns, cities and other localities, enterprises, collective farms, establishments, and organisations. The Decree was the first to prohibit naming objects after the persons while alive. In 1968, the Supreme Council of the Ukrainian Soviet Socialist Republic issued a decree "On the Procedure of Assigning Names of State and Public Figures to Streets, Squares and Other Parts of Localities of the Ukrainian SSR" (Ukaz Prezydii... 1968) reaping the demands of the previous decree.

According to the Constitution of the Ukrainian Soviet Socialist Republic of 1978, local governments were held fully liable for naming public space objects. Article 20 of the Law of the USSR dated December 25, 1979, "On City and Area Council of People's Deputies of the Ukrainian Soviet Socialist Republic" (Zakon Ukrainskoi Radianskoi... 1979), conferred powers on the Council of People's Deputies regarding the naming and renaming of avenues, streets, alleys, squares and the numbering of houses on the territory of the Council. Following the Decree of the Presidium of the Supreme Council of the Ukrainian Soviet Socialist Republic dated March 12, 1981, "On the Procedure of the Administrative and Territorial Arrangement of the Ukrainian Soviet Socialist Republic" (Ukaz Prezydii Verkhovnoi Rady... 1981), the executive committees of the Councils of People's Deputies were empowered to name and rename urban areas and to name them after state and public figures.

\section{Causes of changes in LL and the choice of new names for replacing the signs with Soviet semantics since 1991}

In independent Ukraine, the first regions to exclude Soviet ideological signs from their public space were the western regions, primarily Lviv, Ivano-Frankivsk, Ternopil, and Volyn, where the representatives of the anti-communist national democratic camp formed the core of local authorities. In other territories, the renaming process was slowpaced: in 2007-2010, 2754 names associated with communist ideology were replaced in public space. Following this period, the process was put on hold as the humanitarian policy of the newly elected President Viktor Yanukovych targeted the rehabilitation of the Soviet past.

Other laws of Ukraine were related to the renaming process, including the Law on the Holodomor of 1932-1933, which significantly stimulated changes in $\mathrm{LL}^{1}$.

1 The Law of Ukraine "On Geographical Names" dated May 31, 2005, No. 2604-IV; the Law of Ukraine "On the Holodomor of 1932-1933 in Ukraine" dated November 28, 2006, No. 376-V; the Resolution of Kyiv Court of Appeal dated January 13, 2010, on the criminal case No. 1-33 / 2010 initiated by the Security Service of Ukraine on the fact of genocide in Ukraine in 1932-1933 on the grounds of a crime provided in Part 1 of Article 442 of the Criminal Code 
During the period of the Revolution of Dignity (2013-2014), the process of de-Sovietisation spontaneously made a fresh start. Further still, following the annexation of Crimea by Russia in 2014 and the beginning of the ongoing Russian-Ukrainian war in the Donbass, the toponymic space ceased to be a matter of mere humanitarian policy. In the context of the aggression against Ukraine, it has evolved into one of the key instruments of state national security. Therefore, the President of Ukraine issued the Decree "On Specific Measures of Standardising the Description, Use and Protection of State Symbols of Ukraine" dated August 23, 2014, No. 667/2014, which contained "the prohibition of using the symbols of totalitarian and other non-democratic regimes, self-proclaimed quasi-state entities, terrorist and separatist organizations or groups" (Yak pereimenuvaty vulytsiu... 2014: 9). In April 2015, Verkhovna Rada (the Supreme Council of Ukraine) voted for four de-Communisation laws: a) the Law of Ukraine No. 317-VIII dated 09.04.2015, "On the Condemnation of the Communist and National-Socialist (Nazi) Totalitarian Regimes in Ukraine and the Prohibition of Promoting Their Symbols"; b) the Law of Ukraine No. 316-VIII dated 09.04.2015, "On the Access to the Archives of Repressive Bodies of the Communist Totalitarian Regime of 1917-1991"; c) the Law of Ukraine No. 315-VIII dated 09.04.2015, "On the Perpetuation of the Victory over Nazism in the World War II of 1939-1945"; d) the Law of Ukraine No. 314-VIII dated 09.04.2015, "On the Legal Status and Honouring the Memory of the Fighters for the Independence of Ukraine in the Twentieth Century".

The strategic goal of the above-mentioned laws is to ensure the democratisation of Ukrainian society and its transition to European values. Nonetheless, the transition is hardly possible without overcoming the consequences of totalitarianism. The communication regarding public space renaming between state authorities and the representatives of civil society engaged various political actors: a) Ukrainian Institute of National Memory as a central executive body, whose activity is managed and coordinated by the Cabinet of Ministers of Ukraine and which implements state policy in the sphere of restoration and preservation of national memory of the Ukrainian people; b) political opponents - members of the former Communist Party and the Party of Regions; c) local self-government bodies; d) urban toponymic commissions consisting of public representatives (historians, linguists, architects, sculptors, and local deputies); e) public organisations; f) minority communities residing in particular areas who introduced their suggestions; $g$ ) individual citizens. The organisers of the public discussions independently defined the meeting (a conference, a forum, public hearings, roundtable

of Ukraine; the Law of Ukraine "On Assigning Names (Pseudonyms) of Individuals, Anniversaries and Holiday Dates, Names and Dates of Historical Events to Legal Entities and Objects of Ownership", dated May 24, 2012, No. 4865-VI; the Decree of the Cabinet of Ministers of Ukraine dated October 24, 2012, No. 989, "On the Approval of the Procedure of Public Discussion Concerning the Assignment of Names (Pseudonyms) of Individuals, Anniversaries and Holiday Dates, Names and Dates of Historical Events to Legal Entities and Objects Belonging to them as well as Objects Belonging to Individuals Owners." 
meetings, TV or radio debates, an Internet conference, or an electronic consultation) to attract as many participants as possible (Yak pereimenuvaty vulytsiu ... 2014: 12).

It should be reminded that the condemnation of Communist ideology had been previously issued by different countries of Europe and post-Soviet states: back in 19912010 by Poland, the Czech Republic, Slovakia, Lithuania, Latvia, Estonia, Georgia and the EU (two resolutions of the Parliamentary Assembly of the Council of Europe No. 1481 dated January 26, 2006, and No. 1652 dated January 29, 2009) (Ryabenko 2015).

One of the questions this article asks refers to which entities substituted the elements of Soviet LL laws after the laws of de-Communisation were adopted in 2015. Primarily, the communities reintroduced their historical names, which had been in use prior to the Soviet renaming. Out of 300 historical names, about 70 represent the cultural heritage of indigenous peoples and national communities of Ukraine, namely the Crimean Tatars, Bulgarians, Greeks, Jews, etc. In particular, in the Autonomous Republic of Crimea, the emerging LL predominantly consists of restored historical place names, which were erased by the Stalinist regime after the deportation of the Crimean Tatar people in 1944.

However, in parallel with restoring the pre-Soviet historical names of their residential areas, such as Bakhmut (Artemivsk) or Toretsk (former Dzerzhynsk), the communities offered new names: units with neutral semantics, for instance, Studentska ('Student Street', instead of Krupska Street), Pryvokzalna ('Railway Station Street', instead of Kirov Street), and units with positive semantics (provulok Zapashnyi 'Sweet-Scented Lane', Shchaslyvyi 'Happy Lane', Radisnyi 'Joyful Lane' - instead of Chervonoarmiyskyi 1, Chervonoarmiyskyi 2, Chervonoarmiyskyi 3 'Red Army Lane'). Additionally, new LL signs emphasise state independence (Soborna ('Cathedral Street') Independence), the memory of those who perished during the Revolution of Dignity and in the ongoing Russian-Ukrainian war. For example, five villages were renamed in honour of the native-born soldiers who died in the Donbass in 2014.

It stands to reason that the replacement of Soviet LL proves to be one of the ways of symbolic consolidation of new values. It is convincingly illustrated by the renaming of the city of Artemivsk and Artem Streets, whose names derived from the Communist Party activist known as Artem ${ }^{2}$. In 1924, the pre-Soviet name of the city of Bakhmut was replaced by Artemivsk, while in 2016, the original name was restored. Artem Street could be found in many cities of the Centre, the East and the South of Ukraine. Meanwhile, in 2015-2016, the streets were massively renamed. The new names bring forward the following symbolic meanings connected with peace (vulytsia Myru 'Peace Street'), the environment (provulok Verbnyi 'Willow Lane'), memories of the artists

2 The Bolshevik Comrade Artem (Sergeev) was a Russian Soviet Party and military public figure (1883-1921), the initiator of the Donetsk - Kryvyi Rih Soviet Republic within the Russian Federation (February-March 1918), the leader of the suppression of resistance against the Bolshevik detachments in Ukraine and the military struggle for the establishment of the Soviet power. He held various leading party posts in Ukraine and Russia and was a close friend of Stalin. After his death, Comrade Artem was buried in the Kremlin Wall in Moscow. 
born in the city (Kuindzhi), the fighters for Ukraine (Ukrainian Sich Riflemen), the families that contributed to the development of Ukrainian culture, industry, and banking (vulytsia Alchevskykh 'The Alchevskyis' Street'), the scientists related to the area who gained worldwide recognition (Ilko Borshchak), etc. The names under consideration germinated new narratives aimed at supporting national identity.

It is to be noted that by December 2016, LL signs were largely replaced in Vinnytsia (4882), Volyn (591), Dnipropetrovsk (4122), Donetsk (2904), Zhytomyr (2999), Transcarpathian (501), Zaporizhia (1937), Ivano-Frankivsk 768), Kyiv (3411), Kirovohrad (2929), Luhansk (1456), Lviv (9), Mykolayiv (1528), Odessa (2244), Poltava (3815), Rivne (435), Sumy (2776), Ternopil (98), Kharkiv (4116), Kherson (1628), Khmelnytskyi (1984), Cherkassy (3646), Chernivtsi (635), Chernihiv (2623) Regions, and in the city of Kyiv (148). Altogether 51,493 entities were renamed (Ponad 50 tysiach vulyts... ).

\section{The new LL of Ukraine as a marker of movement from state ideology towards what ideology?}

In 1991, Ukraine gained its independence as a former Soviet Socialist Republic and began to determine its future under severe conditions of post-Soviet economic, political, and spiritual heritage. It is crucial to understand what features distinguish Ukraine's ideology before and after 1991 and how to define this new type of ideology, which is becoming transparent in the new LL.

The reasoning of Soviet ideology is consistent with the understanding of ideology as a form of doctrine serving as a tool for justifying and protecting dominant social interests. This ideology "deliberately conceals the real socio-political state inadequately reflecting the reality through subjectively imposed and a priori set values and ideas, which are nowhere near the objective laws of social development. In particular, these views were espoused by Max Weber, Karl Marx, Carl Mannheim, and Emile Durkheim" (Entsyklopedychnyi slovnyk 2010: 266). Thus, the ideological "curvature of reality", according to Mannheim, enables to consider two types of ideology: partial (individual) and total (state), which is formed and supported within the state (Entsyklopedychnyi slovnyk 2010: 266-267). Soviet ideology is denoted by a range of synonymic terms: Soviet ideology - ideology of Marxism-Leninism - state repressive ideology (Kara-Murza 2012: 75).

Ideological processes in Ukraine at the time of the Soviet Union, known as Sovietisation, had several distinct stages: Ukrainianisation, indigenisation, communisation, and Russification, which came with the terror and the destruction of millions of people. For example, in the 1930s the majority of Ukrainian intellectuals became victims of political repression, while the peasantry went through hardships of artificial famine. These were "political practices of the Communist regime with the domination of authoritarian and bureaucratic methods of state and society, the use of terror and repression against the population, and ideological control of society and personality" (Analitychna dopovid do Shchorichnoho Poslannia... 2016: 185). 
Since 1991, Ukraine has been faced with the creation of new concepts: state development, civil society development, and political nation formation. On the one hand, the former Soviet nomenklatura (higher officials) was engaged in the social development, whereas the post-Soviet society became the core of the Ukrainian political nation. On the other hand, the process was largely predicated upon the collapse of the Soviet mental and institutional forms (Rozumnyi 2016: 12-35) and, simultaneously, upon the search for and formation of society's new value orientation. Through this process, ideology arises as a value system recognised by the majority of people and integrating them into social communities, since, to a large extent, it is on the ground of ideological commitment that the real political socialisation and the unification of people around relevant slogans and ideas take place, inducing them to certain political actions (in Ukraine, the Orange Revolution in 2004 or the Revolution of Dignity in 2013). Such views on the unifying role of ideology were supported by Thomas Parsons, Francis Fukuyama, Jerzy Wiatr, David Easton, and Daniel Bell. In particular, the mobilisation aspect of ideology as a "translation of ideas into social actions" was emphasised by Daniel Bell, the author of the concept of post-industrial society (Entsyklopedychnyi slovnyk 2010: 267).

The data reported here appear to support the assumption that as an instrument of social integration, identification, and mobilisation in the Ukrainian society ideology has a direct bearing on the renaming of symbolic space of Ukrainian LL. It stands to mention, however, that this hypothesis seems to challenge the vision of Bell and Fukayama who hold the view that ideology has already fulfilled its function in the modern world. In a similar vein, some Ukrainian political scientists strongly advocate deideologisation as a sign of a democratic society and as an attempt to ensure the society against the emergence of the totalitarian ideology (Makarenko 2013: 269). The others, in contrast, believe that Ukraine has chosen its own way of development, which offers particular values as certain ideological orientations without having a single marker in social and political discourse (national state ideology, national ideology, state ideology, ideology of statehood, ideology of state development, and ideology of state-building) (Makarenko 2013; Myklashchuk 2009, Karlova 2010, etc.).

In 2004-2014, particularly after the annexation of the Autonomous Republic of Crimea and Russian aggression in the Donbass, "the challenge to national security prompted the rapid growth of national consciousness, which began to actively seek out worldview and value grounds for its identification and to create its specific forms ad hoc" (Rozumnyi 2016: 35). Consequently, the laws of de-Communization appear as an assessment of the previous Soviet stage simultaneously being the manifestation of de-Sovietisation, which is a complex process of understanding de-Communisation, de-Leninisation, de-Stalinisation, de-Russification, and de-colonisation.

Given that the Ukrainian society is currently living under the conditions of the hybrid war, the interaction of ethnopolitical factors (ensuring the level of inter-ethnical tolerance, integrating national minorities into the Ukrainian society, neutralising the attempts to destabilise the ethnopolitical situation, overcoming interregional isolation, 
etc.) plays a crucial role in its consolidation with the national, civil, and regional identities. It is vital to devote close attention to historical memory and language functioning attending to the role of cultural policy, the role of the state in the development of civil society and to de-Communisation as the completion of the post-Soviet state in the modern history of Ukraine (Analitychna dopovid do Shchorichnoho Poslannia... 2016: $185)$.

\section{Conclusion}

The evidence from this study suggests that over the previous century the semantic space of Ukrainian LL has been a site for visualizing ideology. It seems obvious that the Soviet practices of LL design impoverished both the models of creating LL signs and their content giving preference to the markers of the Marxist-Leninist discourse.

The empirical findings indicate that the changes in the content and form of the Soviet entities of public space, which were introduced with a significant delay in independent Ukraine, have freed modern people from the conflict of memories: one associated with the USSR and the other focused on the nation, which lived through the struggle against Bolshevism and the Soviet regime in the post-war period and is currently defending its independence in the context of the Russian aggression.

Ukraine has surmounted severe difficulties of its Soviet and post-Soviet periods. The de-Communisation that triggered the renaming process is a marker of completing these stages. Apparently, the replacement of Soviet LL appears as a clear confirmation of the breach with the state ideology. It is a striking example of the consolidation of new values and the formation of a new national identity in the context of state-building ideology. This term most adequately reflects the reasons and directions of changes that took place in the urban public space of independent Ukraine.

Thus, the interaction of linguistic sign and its ideological content proves that some units of the urban semantic space in Ukraine before and after 1991 are associated with state and state-building ideologies, which are based on different views and different values.

\section{References}

Analitychna dopovid do Shchorichnoho Poslannia Prezydenta Ukrainy do Verkhovnoi Rady Ukrainy "Pro vnutrishnie ta zovnishnie stanovyshche Ukrainy v 2016 rotsi". Kyiv: NISD. http://www. niss.gov.ua/content/articles/files/poslanya_new-cc2e3.pdf (accessed September 15, 2017).

Ben-Rafael, E., E. Shohamy, M. H. Amara and N. Trumpler-Hecht. 2006. Linguistics Landscape as Symbolic Construction of the Public Space: The Case of Israel. International Journal of Multilingualism 3 (1): 7-30.

Ben-Rafael, E., E. Shohamy and M. Barni. 2010. Introduction: An Approach to an "Ordered Disorder”. In Linguistic Landscape in the City, E. Shohamy, E. Ben-Rafael and M. Barni (eds.), xi-xxviii. Bristol, Buffalo, Toronto: Multilingual Matters.

Bever, O. 2010. Linguistic Landscapes of Post-Soviet Ukraine: Multilingualism and Language Policy in Outdoor Media and Advertising. PhD diss., University of Arizona. http://arizona. 
openrepository.com/arizona/bitstream/10150/194464/1/azu_etd_11276_sip1_m.pdf (accessed August 3, 2017).

Bucholtz, M. and K. Hall. 2005. Identity and Interaction: a Sociocultural Linguistic Approach. Discourse Studies 7 (4-5): 585-614.

Entsyklopedychnyi slovnyk $z$ derzhavnoho upravlinnia. 2010. Ideolohiia. Kyiv. 266$267 . \quad$ http://academy.gov.ua/NMKD/library_nadu/Encycloped_vydanniy/14ff57eb-06bd-4b2b-8bfb-ead7f286d5dd.pdf (accessed August 18, 2017).

Halay, O. 2009. Ukrainska urbanonimiia Zakarpattia v 20-21. Avtoref. dysert. na zdobuttia naukovoho stupenia k. f. n. Uzhhorod.

Jaworski, A. and S. Yeung. 2010. Life in the Garden of Eden: The Naming and Imagery of Residential Hong Kong. In Linguistic Landscape in the City, E. Shohamy, E. Ben-Rafael and M. Barni (eds.), 153-181. Bristol, Buffalo, Toronto: Multilingual Matters.

Kara-Murza, A. 2012. Kak filosofskie idei prevrashchaiuesia v repressivnie ideolohii. Politicheskaia kontseptolohia: zhurnal metadistsiplinarnykh issledovaniy 2: 62-78.

Karasevych, A. and L. Shachkovska. 2016. Ideolohiia politychna. Politolohichna entsyklopediia. Navchalnyi posibnyk dlia vyshchykh navchalnykh zakladiv Knyha III. LITERY - Zh, Z, I, K, L: 137-138.

Karlova, V. 2010. Problemy formuvannia zahalnonatsionalnoi ideolohii v Ukraini. Filosofiia, metodolohiia, teoriia ta istoriia derzhavnoho upravlinnia 4: 17-24.

Khrushkova, O. 2016. Struktura ta funktsiine navantazhennia pysemnykh nosiiv informatsii suchasnoho mista. Dnipro.

Konstytutsiia (Osnovnyi Zakon) Ukrainskoi Radianskoi Sotsialistychnoi Respubliky. http:// gska2.rada.gov.ua/site/const/istoriya/1978.html (accessed September 2, 2017).

Kozlovets, M. 2009. Fenomen natsionalnoi identychnosti: vyklyky hlobalizatsii: Monohrafia. Zhytomyr: Vyd-vo ZhDU im. I. Franka.

Kyrylyuk, F. 2009. Filosofiia politychnoi ideolohii. Kyiv: Tsentr uchbovoyi literatury.

Landry, R. and R. Y. Bourhis.1997. Linguistic Landscape and Ethnolinguistic Vitality: An Empirical Study. Journal of Language and Social Psychology 16 (1): 23-49.

Luchyk, V. 2009. Pryntsypy i kryteriyi nominatsiyi ta vidnovlennia istorychnykh nazv u toponimiyi Ukrayiny. Ukrainska mova 4: 20-33.

Makarenko, O. 2012. Sutnist i rol derzhavnoi ideolohii v rozbudovi derzhavy v Ukraini. Aktualni problemy derzhavotvorennia 1 (43): 268-276.

Matsyuk, H. 2014. Pro pryrodu vzaiemodii movy ta identychnosti v Ukraini (na materiali miskoho urbanimikonu radianskoho ta postradianskoho periodiv). In Ukrainotsentryzm naukovoho sumlinnia. Zbirnyk naukovykh prats na poshanu profesora Zenoviia Terlaka, 539-555. Lviv: Liha-Pres.

Myklashchuk, I. 2009. Derzhavotvorcha ideolohiia yak chynnyk demokratychnoho rozvytku Ukrainy. Politychnyi menedzhment 5 (38): 63-71.

Nahorna, L. 2008. Rehionalna identychnist: ukrainskyi kontekst. Kyiv: IPiEND imeni I.F.Kurasa NAN Ukrainy.

Pavlenko, A. 2010. Linguistics Landscape of Kyiv, Ukraine: a Diachronic Study. In Linguistic Landscape in the City, E. Shohamy, E. Ben-Rafael and M. Barni (eds.), 133-150. Bristol, Buffalo, Toronto: Multilingual Matters.

Pavlenko. A. 2009. Language conflict in Post-Soviet Linguistic Landscape. Journal of Slavic Linguistics 17 (1-2): 247-274.

Ponad 50 tysiach vulyts zminyly nazvy vprodovzh 2016 roku. Ukrainskyi instytut natsionalnoi 
pamiati. http://www.memory.gov.ua/news/ponad-50-tisyach-vulits-zminili-nazvi-vprodovzh-2016-roku (accessed August 17, 2017).

Postanova Apeliatsiinoho sudu mista Kyieva vid 13 sichnia 2010 roku po kryminalnii spravi No 1-33/2010, porushenii Sluzhboiu bezpeky Ukrainy za faktom vchynennia henotsydu v Ukraini v 1932-1933 rokakh za oznakamy zlochynu, peredbachenoho ch. 1 st. $442 \mathrm{KK}$ Ukrainy. http://khpg.org/index.php?id=1265039604 (accessed September 20, 2017).

Postanova Kabinetu Ministriv Ukrainy vid 24 zhovtnia 2012 roku № 989 “Pro zatverdzhennia poriadku provedennia hromadskoho obhovorennia pid chas rozhliadu pytan pro prysvoiennia yurydychnym osobam ta obiektam prava vlasnosti, yaki za nymy zakripleni, obiektam prava vlasnosti, yaki nalezhat fizychnym osobam, imen (psevdonimiv) fizychnykh osib, yuvileinykh ta sviatkovykh dat, nazv i dat istorychnykh podii”. http://zakon5.rada.gov.ua/ laws/show/989-2012-\%D0\%BF (accessed August 2, 2017).

Rozumnyi, M. 2016. Vyklyky natsionalnoho samovyznachennia: monohrafia. Kyiv: NISD.

Ryabenko, S. Chy vidpovidaie dekomunizatsiia Ukrainy yevropeiskii praktytsi. 21 kvitnia 2015. https://ukr.lb.ua/society/2015/04/21/302433_chi_vidpovidaie_dekomunizatsiya_ ukraini.html (accessed July 16, 2017).

Tytarenko, A. 2015. Urbanonimiia Kryvoho Rohu: struktura, semantyka, funktsionuvannia: avtoref. dys. ... kand. filol. nauk. Dnipropetrovsk.

Ukaz Prezydii Verkhovnoi Rady Ukrainskoi RSR "Pro poriadok prysvoiennia imen derzhavnykh i hromadskykh diiachiv vulytsiam, ploshcham ta inshym chastynam naselenykh punktiv Ukrainskoi RSR”. 1968. Vidomosti Verkhovnoi Rady URSR 10: 91.

Ukaz Prezydii Verkhovnoi Rady Ukrainskoi RSR "Pro poriadok vyrishennia pytan administratyvno-terytorialnoho ustroiu Ukrainskoi RSR” vid 12 bereznia 1981 roku No 1654. http:// zakon1.rada.gov.ua/laws/show/1654-10. (accessed August 23, 2017).

Ukaz Prezydyuma Verkhovnoho Soveta SSSR ob uporiadochivanii dela prisvoeniia imen gosudarstvennykh i obshchestvennykh deiatelei kraiam, oblastiam, raionam, a takzhe gorodam i drugim naselennym punktam, predpriiatiiam, kolkhozam, uchrezhdeniiam i organizatsiiam. 1957. Vedomosti Verkhovnogo Soveta Soiuza Sovetskykh Sotsialisticheskykh Respublik 19: 579-581.

Yak pereimenuvaty vulytsiu. Pravovi zasady pereimenuvannia vulyts, provulkiv, prospektiv, ploshch, parkiv, skveriv, mostiv ta inshykh sporud, roztashovanykh na terytorii naselenykh punktiv. Metodychnyi zbirnyk. 2014. Kyiv.

Yatskiv, R. Do pytannia pro urbanonimy Drohobycha. http://ddpu.drohobych.net/native word/wp-content/uploads/2016/04/2013-40 (accessed June 13, 2017).

Zakon Ukrainskoi Radianskoi Sotsialistychnoi Respubliky "Pro misku, raionnu v misti Radu narodnykh deputativ Ukrainskoi RSR”. 1979. Vidomosti Verkhovnoi rady URSR 52 (37-74).

Zakon Ukrainy "Pro heohrafichni nazvy". 2005. Visnyk Verkhovnoi Rady 27.

Zakon Ukrainy "Pro Holodomor 1932-1933 rokiv v Ukraini” vid 28 lystopada 2006 roku No 376-V. 2006. Vidomosti Verkhovnoi Rady Ukrainy 50.

Zakon Ukrainy "Pro prysvoiennia yurydychnym osobam ta obiektam prava vlasnosti imen (psevdonimiv) fizychnykh osib, yuvileinykh ta sviatkovykh dat, nazv i dat istorychnykh podii” 24 travnia 2012 roku No 4865-VI . 2013. Vidomosti Verkhovnoi Rady (VVR) 17.

Zakon Ukrainy vid 09.04.2015 No 314-VIII "Pro pravovyi status ta vshanuvannia pamiati bortsiv za nezalezhnist Ukrainy u XX stolitti”. http://www.memory.gov.ua/laws/law-ukraine-legal-status-and-honoring-memory-fighters-ukraines-independence-twentieth-century (accessed June 17, 2017). 
Zakon Ukrainy vid 09.04.2015 No 315-VIII "Pro uvichnennia peremohy nad natsyzmom u Druhii svitovii viini 1939-1945 rokiv”. http://www.memory.gov.ua/laws/law-ukraine-perpetuation-victory-over-nazism-world-war-ii-1939-1945 (accessed May 23, 2017).

Zakon Ukrainy vid 09.04.2015 No 316-VIII "Pro dostup do arkhiviv represyvnykh orhaniv komunistychnoho totalitarnoho rezhymu 1917-1991 rokiv”. http://www.memory.gov. ua/laws/law-ukraine-access-archives-repressive-agencies-totalitarian-communist-regime-1917-1991. (accessed May 23, 2017).

Zakon Ukrainy vid 09.04.2015 No 317-VIII "Pro zasudzhennia komunistychnoho ta natsional-sotsialistychnoho (natsystskoho) totalitarnykh rezhymiv v Ukraini ta zaboronu propahandy yikhnoi symvoliky". http://www.memory.gov.ua/laws/law-ukraine-condemnation-communist-and-national-socialist-nazi-regimes-and-prohibition-propagan (accessed June 18, 2017). 